\title{
Sharing Economies, Technologies, and the Changing Nature of Urban Public Space in Medium-Sized Cities
}

\author{
Economia compartilhada, tecnologias e a natureza mutável dos \\ espaços públicos urbanos nas cidades médias
}

\section{Economía compartida, tecnologías y la naturaleza cambiante del espacio público urbano en ciudades medias}

\author{
Celen Pasalar \\ celen_pasalar@ncsu.edu \\ North Carolina State University, Raleigh, NC, Estados Unidos da América
}

George Dewey Hallowell

george_hallowell@ncsu.edu

North Carolina State University, Raleigh, NC, Estados Unidos da América

\begin{abstract}
Public spaces ensure functional operation and resource sharing in all cities. Streets, squares, and parks afford cultural, socio-economic, and ecological activities benefitting society. However, technology and sharing economies are changing the use of urban spaces. Planners and designers must, therefore, consider the evolution of sharing and other technologies that continue to alter the formation of space in growing medium-sized cities. Public space in a city is a spectrum from the streets to the privacy within homes, and this transect is now being blurred by sharing technology and practices. This paper examines the impact that new technologies and sharing economies have on the way public spaces are generated and used, and what opportunities exist to mitigate negative changes using a human-centered focus and ecological wisdom.
\end{abstract}

Keywords: technology effects; ecological wisdom; public to private economy; urban spaces; technological affordances.

Resumo: Espaços públicos asseguram o funcionamento operacional e o compartilhamento de recursos nas cidades. Ruas, praças e parques oferecem atividades culturais, socioeconômicas e ecológicas, beneficiando a sociedade. No entanto, a economia e tecnologias de compartilhamento estão mudando o uso dos espaços urbanos. Planejadores e designers, portanto, devem considerar a evolução do compartilhamento e outras tecnologias que continuam a alterar a formação do espaço nas cidades médias em crescimento. $O$ espaço público em uma cidade abrange um espectro desde as ruas até a privacidade do lar; transecto este que agora está sendo borrado, compartilhando tecnologia e práticas. Este artigo examina o impacto das novas tecnologias e economias de compartilhamento na maneira como espaços públicos estão sendo gerados e usados, e quais as oportunidades para mitigar alterações negativas, com foco centrado nas pessoas e na sabedoria ecológica.

Palavras-chave: efeitos da tecnologia; sabedoria ecológica; economia pública em espaços privados; espaços urbanos; possibilidades tecnológicas. 
Resumen: Espacios públicos garantizan la operación funcional y recursos compartidos en las ciudades. Calles, plazas y parques permiten actividades culturales, socioeconómico y ecológicas, beneficiando a la sociedad. Sin embargo, la economía y tecnología de compartir están cambiando el uso de los espacios urbanos. Planificadores y diseñadores, por tanto, deben considerar la evolución de compartir y otras tecnologías que alteran la formación del espacio en ciudades de tamaño mediano en crecimiento. Espacio público en una ciudad abarca un espectro desde las calles a la privacidad de un hogar, y este transecto ahora se borra por intercambio de tecnología y prácticas. Este artículo examina el impacto de las nuevas tecnologías y economías de compartimiento en la manera que los espacios públicos son generados y utilizados, y qué oportunidades existen para mitigar los cambios negativos mediante un enfoque centrado en el humano y la sabiduría ecológica.

Palabras clave: efectos de la tecnología; sabiduría ecológica; economía pública a espacios privados; espacios urbanos; posibilidades tecnológicas.

\section{INTRODUCTION}

As global population increases, more and more people are finding their way into cities. By 2050 almost 2.5 billion people are expected to move into cities around the world, and a large share of that urban migration in the U.S. will probably occur in medium-sized cities (SISSON, 2018; MCFARLAND, 2017). Even while researchers are trying to decipher the evolution of our urban experience, emerging technological advances are continuing to disrupt how we live in and around cities. The increasing interest in Smart Cities, efficiency, safety, new business models, faster services and leisure activities, has led to evolving devices such as autonomous cars, smart phones, digital applications, virtual platforms, and so on. A recent World Bank report suggests that 'smart cities' is about rethinking cities as inclusive, integrated, and livable (2012). However, observations reveal that people are more and more disconnected, separated or filtered from the real settings including public spaces and natural surfaces in our cities such as streets, squares, riversides, bike lanes, etc. (PASALAR; HALLOWELL, 2018; FURMAN, 2017).

Through the course of time, urban public spaces have ensured the functional operation and resource sharing of a city. For centuries streets, squares, parks and plazas have played a key role in affording cultural, social, political, biodiverse, and economic activities for the benefit of society. However, because of new technologies and the evolving concept of a sharing economy within the urban realm, the use of public spaces in cities has also been changing. Sharing economies, often defined as collaborative consumption or peer-to-peer economies, provide a process for underused resources to be easily shared or transferred to others to create more value or bring more benefits to society. As part of the ongoing smart city discussions, planners and economists are looking into these concepts, and questioning the socio-cultural and economic effects, and ecological wisdom of a sharing economy on the use of public space. For decades, cities have looked at public spaces to "segregate, contain, and enclose uses; homogenize urban form; and prohibit anything that falls outside a narrow cadre of activities" (LOUKAITOU-SIDERIS; EHRENFEUCHT; EHRENFEUCHT, 2009, p. 
272; FURMAN, 2017). However, designers are now considering how urban public spaces might provide affordances that help create new relationships and uses through technology. In this era of evolving technology, what Mitchell $(1995$, p. 8) describes as the "electronic agora" of cyberspace, changes our thoughts about what constitutes an urban gathering place, urban life, and sense of community. In ancient public spaces, people represented themselves by their "clothing, body language, speech, and behavior" (MITCHELL, 1995, p. 7-9) and through interactions in those physical plazas and parks. But how does that common behavior and understanding change in this new age of digital representation? Artists have also been harnessing technology to create temporary art that provides engaging public experiences within urban spaces (FURMAN, 2017; LEGRADY, 1999).

Therefore, our research question for this paper is how do new technologies and a sharing economy change the activities and formation of space in urban public spaces, and can those changes occur as part of an ecological wisdom framework helping to create healthy social and ecological systems in medium-sized cities. In response to these questions, this paper explores the impacts that a sharing economy may have on the way urban public spaces are generated, used, and changed. As part of the theoretical foundations, it discusses Lefebvre's idea that space is socially produced and changes over time depending on the social conventions and technological advances (LEFEBVRE, 1991). Gibson's 'affordance theory' also states that we perceive our world through object shapes, spatial relationships, and our perceptions of object possibilities (GIBSON, 1977; FURMAN, 2017).

With this context in mind, we suggest that space in cities is a continuum from the most public, such as the street to the privacy within homes. We investigate the possibility that this spectrum is being shifted or blurred by the technologies and socio-cultural, political, and economic practices of the sharing economy. At the most public end, we review the use of space along streets that will most likely change as autonomous cars and sharing technologies alter parking and drop-off patterns, as well as dominion over the road. At the other extreme of the public to privacy spectrum, we investigate how sharing technologies such as Airbnb may change the intimate character of our neighborhoods by introducing the traditional hotel infrastructure into our private homes and change the relationships between living rooms and public spaces such as residential urban streets and neighborhoods.

\section{THEORETICAL FOUNDATION AND CONCEPTS}

\section{The Public to Private Continuum in Urban Spaces}

Leary-Owhin (2016) in Exploring the Production of Urban Space presents the implications of Lefebvre's three types of space - abstract space, differential space, and counter projects. Lefebvre uses the term differential space to describe places that are often in transition, and which prioritize human-use value over economic value. This further emphasizes the complexities of public and private interests on space, and asks how social struggles and 
changes contribute to urban development and evolving demands by our societies. This result in the expectations that cities spatially need to adapt and evolve to changing social, political, and economic circumstances (LEARY-OWHIN, 2016).

It is in the public spaces of cities - streets, squares, plazas, and parks - that varying characteristics of urban life and society are created, observed and reproduced. Public space is always a work in progress and is never a finished product (LEARY-OWHIN, 2016). It is composed of bricks, stone, concrete, steel and glass, but crucially it is produced, and reproduced continually through social struggle or activities (LEARY-OWHIN, 2016). In that sense, Lefebvre problematized urban space, insisting it was not simply a neutral container, provoking its reconceptualization as both material product and social process.

In a treatise on urban public and private spaces, Madanipour (2003) promulgated two important themes. First, that private and public spheres influence and continuously shape each other and are therefore essentially interdependent. As the two spheres push and pull against each other, the boundary between them, and indistinct areas of semiprivacy, can blur and change. The second theme, of specific interest here, is that "public and private spaces are a continuum where many semi-public or semi-private spaces can be identified, as the two realms meet through shades of privacy and publicity rather than clearly cut separation" (MADANIPOUR, 2003, p. 210; GEHL, 1971, p. 59). Our next step in this discussion is to examine how this continuum of public to private in the urban realm of our cities might be changing. Of immediate concern is not whether "technological advances have despatialized and fragmented urban space" (MADANIPOUR, 2003, p. 208), nor how much privacy is wanted or needed (JACOBS, 1961; KILIAN, 1998; SENNETT, 1977). Instead, we are focused on how the edges and boundaries of this continuum are being shifted or blurred by the technologies and socio-cultural and economic practices of the sharing economy.

\section{Sharing Economies and Cities}

Schor (2016) suggests that finding a solid definition of the term sharing economy that includes most common usages is "nearly impossible," especially in our rapidly changing urban economy. Several recurrent guidelines and origins do however provide some common understanding of the term in our current lexicon. Researchers in the field often agree that it was information and communications technologies after Web 2.0 that first enabled the rise of sharing or collaborative consumption (HAMARI; SJÖKLINT; UKKONEN, 2016). They describe sharing economy or collaborative consumption as the peer-to-peer-based activities of obtaining, giving, or sharing the access to goods and services, coordinated through community-based online services. In its original intent, the sharing economy was about the sharing of assets that sat idle, typically using technology or online platforms, in the hope that it would produce environmental, economic, social and practical benefits. For the World Economic Forum, Rinne (2017) defines sharing economy as focusing on the sharing of underutilized assets, no matter if monetized or not, in ways to improve efficiency, 
sustainability, and community. Adding the idea of technology and an online structure to Rinne's definition of sharing economy, gives a fairly complete understanding to the concept. In the ideal, sharing instead of owning helps individuals and organizations earn income, lower carbon footprints, save money, increase social capital, boost community, build trust, and even enhance convenience and choice.

Over the last decade, the concept of a sharing economy and collaborative consumption have been evolving. In early discussions of the sharing concept, Time Magazine (WALSH, 2011) had named collaborative consumption, as one of "10 ideas that will change the world." Botsman and Rogers (2010) and Tussyadiah (2015) also suggested at about the same time that peer-to-peer collaborative consumption fosters community. Recently, however, Rinne (2017) noted that although the sharing economy has matured and vastly increased in size, "it has become a victim of its own success." Indeed, a number of people have argued that this new type of economy is not really 'sharing' at all, and to a certain extent this is correct. Rinne (2017) goes on to say that 'sharewashing' going on as companies latching onto the term because it makes them part of a hot trend. Part of the confusion in terms comes from the often hidden difference between peer-to-peer and business-to-peer models of sharing, and also between nonprofit and for-profit. In order to clarify these issues, Schor (2016) suggests dividing the concept of sharing economy into four categories: i) recirculation of goods; ii) increased utilization of durable assets; iii) exchange of services; and iv) sharing of productive assets.

In our examination of how the sharing economy is potentially changing the nature of urban public spaces, we are particularly focused on Schor's idea of the increased utilization of durable assets (such as car, e.g. Zipcar; ride sharing, e.g. Uber; or house sharing, e.g. Airbnb), and sharing of productive assets (such as office space sharing, e.g. WeWork). In both instances, we are interested in spatial implications of these services and the pressing expectations to envision the formation of future urban spaces.

\section{AN OVERVIEW OF ADVANCES IN TECHNOLOGY}

Technological advances have continued to change our daily lives by disrupting how we do things for centuries. Recent examples include Uber and Lyft providing services by connecting people to nearby drivers that enable people to go anywhere they want easier, quicker and more affordably. As an alternative to private taxi services, Uber disrupted the transportation sector and the mobility behavior. It also introduced a shared business model that created a network of drivers using their personal cars, while connecting them to nearby customers through the use of an app in addition to navigation systems, such as Google Maps or Waze. Using smart routes suggested by such apps, Uber is now designating pick-up points for multiple riders reducing the time needed to pick up differing fares. As companies similar to Uber are emerging through rideshare models, more cars are competing for curbside collection/drop off points challenging public transit ridership beyond the traditional taxis. Uber is now designating nodes as collection points, and access to those 
nodes is becoming important. What this suggests is reconsideration of transit-oriented developments and formation of new spaces as nodes that are also suitable for flexible transportation. This also requires a rethinking of infrastructure where curbsides and pickup stations in the public right-of-way have become an important commodity in infrastructure as bus stop areas did in the past. This also requires a city to reconsider how it manages public property. As more travelers are opting for shared rides instead of using or owning their own cars, the trip destinations are shifting from parking spaces (i.e. as nodes to store cars) to streets and curbsides (i.e. as nodes for people to congregate), thus generating a congestion problem for roadways as well as deserted parking lot spaces. This change to road edges and parking lots could also be a positive outcome, if they are repurposed to meaningful public spaces with sufficient ecological wisdom.

With car sharing and the advent of autonomous vehicles (AV), land use and urban density will also be affected. Recent research focusing on smart cities suggest that AVs will help transition mobility from a personal ownership of automobiles to a collective shared/service paradigm (YOUNG; LIEBERKNECHT, 2018). Along with the substantial potential benefits of $\mathrm{AVs}$, including environmental and health, designers must also prepare for possible negative effects in the form of urban and suburban sprawl. Researchers have warned that a possible side effect of full vehicle automation may be to induce higher vehicle-miles traveled (WADUD; MACKENZIE; LEIBY, 2016). There is a need for more study that will further examine how automated vehicles might impact the future of the built environment, specifically whether autonomous vehicles will encourage denser urban development patterns or encourage more suburban sprawl, and thereby potentially exacerbating negative health outcomes (CRAYTON; MEIER, 2017). Some studies even suggest that private ownership of AVs may not only support, but actually lead to "an increase in the amount of land dedicated to new roadway infrastructure, thus encouraging dependency on private vehicles and community sprawl; increase congestion, trip length, energy consumption, air and noise pollution; and counteract efforts to promote mixed-use facilities, uptake of transit, and active travel options" (ROJAS-RUEDA, 2017).

Another sharing technology that has significantly disrupted centuries of urban socio-economic behavior is online accommodation or house sharing. Founded in 2008 in San Francisco, Airbnb has emerged as a powerful force, operating an online marketplace and hospitality service for people to lease or rent short-term lodging. Airbnb, as well as HomeAway, VRBO, FlipKey, and many other short-term rental websites, now provide access to holiday cottages, apartments, and homes around the world. Although these accommodation rental services can alleviate cost and complexities for urban travelers, they are also providing challenges for planners and designers in many cities. The experiential quality of an urban area can be changed through this business model, which enables people to rent and experience private homes and apartments distributed in and around cities rather than being limited to specific hotel districts that have been typically clustered in certain areas of downtowns, tourist areas, or key locations such as airports. Airbnb can also allow tourists to break away from the norm and enjoy the city as the locals do. In recent years, researchers, community groups and housing advocates in cities around 
the world have begun to sound the alarm about the impact Airbnb is having on issues like affordable housing in their neighborhoods (WACHSMUTH; WEISLER, 2018; BJH ADVISORS, 2016; LEE, 2016). Common concerns cited include the loss of housing supply, widespread and sometimes racialized gentrification, and increases to the median longterm rent in the city. Studies have also opened a discussion about the change in stability and privacy in previously quiet communities and impact on permanent residents' quality of life (WACHSMUTH et al., 2018).

An issue that urban planners, architects and landscape architects should also consider is, without zoning or operational control of house sharing on a block-by-block basis; will the increase and continued use of short-term rental sharing change the design expectations for urban neighborhoods? It is also worth considering what impact conversions of individual units or even rooms of apartment and condominium buildings will have on the public to private continuum from the sidewalk into the most intimate rooms of your own home.

Certainly, these new sharing technologies have the power to reshape streetscapes and urban public spaces for better and/or worse. However, the popular technology of our times has focused on the creation of mechanical, controllable, and profitable means abstracted from the particularities of place (MUMFORD, 1997; YOUNG et al., 2018). Instead of enabling unique, place-based, information-rich cities to emerge, growing medium-sized cities are mimicking similar developments that are occurring in large metropolitan cities of China, Singapore, and so on (YOUNG et al., 2018).

Do exist tools that designers can use to mitigate potential negative disruptions private areas of houses and apartments? Can these tools also mitigate the social disruption along the sidewalks and semi-public spaces in the adjoining streetscape?

\section{THE CHANGING NATURE OF PUBLIC SPACES}

In Jan Gehl's seminal work, Life between Buildings (1971), he prescribes a probabilistic understanding about how design is linked to behavior in public spaces. Gehl suggests that by providing the necessary ingredients for activities, designers can influence how many people use public spaces, how long individual and group activities last in those spaces, and which types of activities can develop (CARMONA et al., 2003). He notes that public spaces afford the opportunity for people to be "among, to see and to hear others, to experience other people functioning in various situations" (GEHL, 1971, p. 9-14). He further divides these contact opportunities into a range of three outdoor activities from low contact intensity to high contact intensity. At the lowest end of his scale are Necessary Activities that are largely compulsory, such as walking to work or school, waiting for a bus, delivering the mail, etc. Although a person is able to view and hear the social action in the space, because they have no choice in being there, they are only slightly influenced by the setting. Gehl (1971) describes the middle of the range of influence as Optional Activities, such as taking a walk, sitting at a sidewalk cafe or park bench, or people-watching. Because these optional activities are voluntary, they are of course influenced by weather 
and affordances for sitting or playing and can provide richer involvement in the space. The highest degree of contact intensity is Social Activities. These activities depend on the presence of other people in the space, even to accomplish simple social contacts such as greeting or conversation. These social activities can occur spontaneously as a direct result of merely sitting in the space or moving through it, or social activities can be supported by affordances that support longer periods of conversation or communal activities, such as tables and chairs, music performance stages, or physical support for play or simple sport functions. The essence of Gehl's argument is that in poorly designed public spaces, only the most necessary activities will occur. In higher quality spaces, necessary activities will continue to exist at the same rate, but people will choose to spend more time in the space, and perhaps more importantly, a wider range of activities will occur that support richer and more durable social connectedness.

Designers typically evaluate public spaces by looking at the highest level of social activities, for example how many people use the space for how long, how many users during what time of the day, etc. However, we are reminded that low-intensity contact afforded by public spaces are best described and measured by the situation when they are missing. Gehl (1971) notes that if necessary activity in urban public spaces is missing, "the lower end of the contact scale also disappears. The varied transitional forms between being alone and being together have also disappeared. The boundaries between isolation and contact become sharper" (GEHL, 1971, p. 17). On the other hand, when simple forms of low-intensity contact are present, other more permanent and intense forms of contact can grow. Historically, the possibility of running into neighbors and co-workers usually during our daily comings and goings encouraged a valuable opportunity to establish and maintain friends in a relaxed and undemanding way. This has also been one of the primary reasons that "adults and children maintain more frequent and closer contact with people that live, work, or go to school near them, for ages, it has been the simplest way to stay in touch" (CARMONA et al., 2003, p. 106-109).

An initial point to consider is how Gehl's necessary activities in urban public spaces, at the lowest order of contact intensity, will change with new technologies and the sharing economy. If the daily trip to work or school is comprised of merely scheduling an Uber or Lyft driver from within a person's own home and walking directly to the car upon its arrival, do any of the accidental or impromptu sources for social interaction remain? In the mold of a suburban family loading into their car from within their own garage before leaving their home; has even the simplest opportunity for contact in the walk to school or waiting on the corner for the bus been lost? Some have argued that car, ride and other forms of sharing in either peer-to-peer or in business-to-peer organization such as Uber or Airbnb, social interactions and the possibilities for longer term connections has been increased. However, the limited range of studies that have looked at sharing and social connections have shown mixed results. In fact, a study of one of the early peer-to-peer house sharing organizations, CouchSurfing, showed that "this case illustrates a process of disenchantment created by technology, where technology increases the ease with which we form friendships around common cultural interests and, at the same time, diminishes the 
bonding power of these experiences" (PARIGI; STATE, 2014, p.166). In another example, a study of car sharing found "that the two parties to the transaction often never met on account of remote access technology" (SCHOR, 2016, p.6; FENTON, 2013). Sharing sites sometimes advertise social connections as a feature of their activities, and participants often describe a desire to meet new people or get to know their neighbors (SCHOR, 2016), but the evidence for prolonged social connections developing from sharing are not clear at this point. New research is certainly needed to develop a better understanding of the strength and longevity of potential social connections deriving from new technologies and the sharing economy.

In further consideration of necessary activities in public spaces, Lynch (1960) noted that we are not simply observers of the urban spectacle but are ourselves a part of it. It is a common thread among urban designers that presence in urban public spaces is a necessity for their social, cultural and economic success (CHO, 2016; CARMONA, 2015; GEHL, 1971; MADANIPOUR, 2003; LYNCH, 1960). However, as we have asked in previous studies, how would that statement change if we are not physically or mentally present? (PASALAR; HALLOWELL, 2018) Although that question would have been a non sequitur at the time that Lynch penned The Image of the City, it is certainly of consequence in today's world of remote viewing via Google Street View, or panoramic scenes created through synchronous virtual reality images of distant places. Before the current digital revolution, gathering in public plazas and on the street also gave a physical message by the clothing people wore, their body language and speech, and by what interactions and behavior they were engaged in (MITCHELL, 1995). But how has that changed with new virtual environments? Although we have a sense of being in the space that we are viewing, we are not contributing to the social vibrancy, or any of Gehl's higher order of social activity.

Designers and urban researchers must also consider the impact that distractions from new technologies have on the social and cultural success of urban public spaces. In the last few years, cities like New York, Chongqing, China, and Antwerp, Belgium have begun to install lane markers across public spaces and along sidewalks in order to avoid smartphone addicts risking life and limb as they go about their day, with near misses and collisions with other pedestrians occurring at an ever-increasing rate (BENEDICTUS, 2014; MOOG, 2015). If lane markers are necessary to avoid calamity, it seems unlikely that even minimal social interaction is occurring between the smartphone user and other occupants of the street or urban plaza. Designers should examine the possible effects on the success of those urban spaces due to technological distraction, and consider physical or digital affordances that might draw public space users out of their privacy bubbles. For example, researchers and designers have suggested large interactive digital video displays (BRIGNULL; ROGERS, 2003; VOGEL; BALAKRISHNAN, 2004) as interventions in public urban spaces to re-energize and engage users. The success of using digital displays to engage public space users seems to hinge on avoiding social embarrassment. One means of achieving this is to have strong physical and social affordances that encourage people to "cross the thresholds from peripheral awareness, to focal awareness, to participation and back again, without becoming self-conscious" (BRIGNULL; ROGERS, 2003, p. 8; 
LEGRADY, 1999) as they interact with the displays. Part of the solution to smartphone and tech distractions may also come from physical affordances along the projected pathways that promote alternative social activities, such as pop-up stores or restaurants, flexible seating, small music or busker venues, or pre-programmed activities designed to temporarily engage the users of the urban public space.

\section{The Public Realm of the Street}

At the most extreme end of the private-public continuum is the public space of the street. Joseph Rykwert (1978, p. 23) described the use of the street as "a locus of personal exchange and communication." He further advocated that the space of the street be promoted for that use by both business and government, conceptually subordinating the more obvious uses of transporting people, goods, and services along its axis. He noted that the failure to prioritize this primary exchange and communication function of the street would risk a "growing alienation of the city dweller from his physical environment." Others have also tried to differentiate the idea of the street as public space versus linear corridor, and in this sense, have recognized that streets are a critical part of the external public realm (MEHTA, 2013). "Accessible to all, these spaces constitute public space in its purest form" (CARMONA et al., 2003, p.111). In discussing social and spatial forms of urban public plazas, Whyte (1980) described the importance of a street by saying that the most critical component of an urban public plaza is not the plaza itself. He stated that "It is the street. The other amenities we have been discussing are indeed important: sitting space, sun, trees, water, food. But, they can be added. The relationship to the street is integral, and it is far and away the critical design factor." (WHITE, 1980, p. 54). In a study of a new urban plaza in the medium-sized city of Raleigh, North Carolina, Elabd and Hallowell (2014) found that even though the plaza was bisected by a major street, it could still function well, if the basic ingredients posited by Whyte (1980) and others were thoughtfully combined with new approaches to flexible auto sharing and drop-off zones, street access, and social and ecological amenities (Fig. 1). 
Figure 1: City Plaza in Raleigh with easy auto drop-off and access to street.

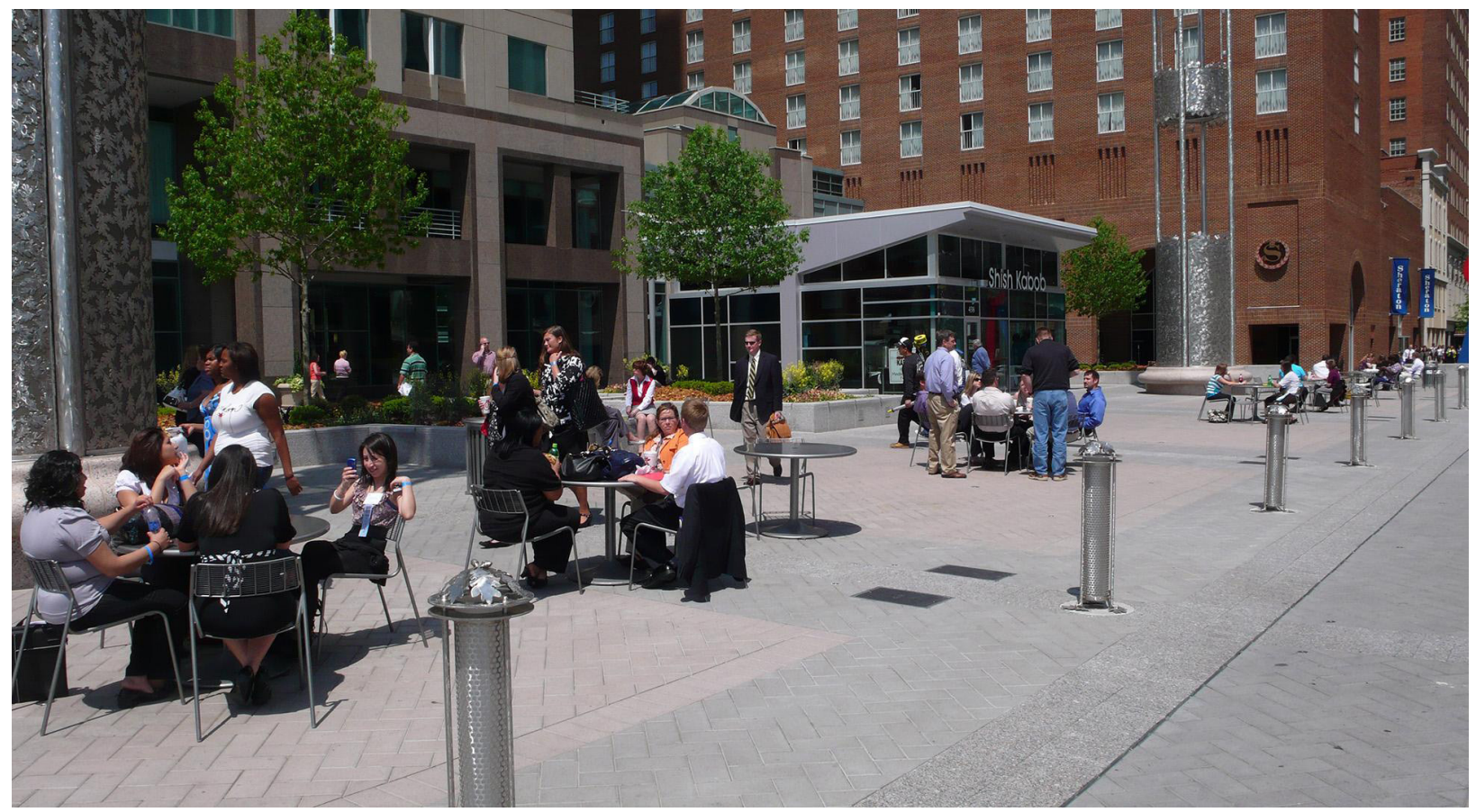

Photo Source: George Hallowell

Given the critical nature of the street to provide a locus of "personal exchange and communication," how might new technologies and the sharing economy alter the social space in and along our city streets? While we have already discussed the potential of losing Gehl's necessary activities as we increase the use of sharing technologies such as Uber or Lyft, we can also envision a tremendous advantage to the urban space of the street-in recaptured parking spaces. Carlo Ratti has suggested that "an average vehicle in the US is parked for a staggering 95 percent of the time" (DOCKRILL, 2016). He adds that car sharing is already reducing the need for parking spaces, thus it has been estimated that every shared car removes between 10 and 30 privately cars from the streets. It seems inevitable then that the eventual widespread use of AVs could essentially remove on-street parking. The prospect of converting the zone of what is now parking along our streetscapes to social activity zones, such as parklets, could be tremendously impactful to vibrancy and social interaction within the space of the street. With enough ecological wisdom, these recovered parking areas could also increase biodiversity and create zones of healthy social and ecological systems. A blueprint for the idea of creating a new zone of parklets along city streets to replace car parking originated in San Francisco in 2005 through Rebar Studio, essentially as an act of guerrilla art in public space (PECKENHAM, 2014). That original intervention has become an international success, now referred to as Park(ing) Day. Can we as designers help neighborhoods benefit from this conversion of the parking zone along our city streets? Additionally, what affordances, such as car drop-off stands, benches, tables, pop-up retail stands, digital displays, and areas of biodiversity could be introduced in this newly converted public zone to enhance Gehl's idea of social activities? 


\section{Ecological Wisdom as an Opportunity for Medium-Sized Cities}

Ecological wisdom is a relatively new concept that has been receiving attention in academic research and influencing the conversations in planning and design fields. It is not only about the environment and ecology, but it is derived from the biological nature of humans and everything they do, produce, and excrete, as part of nature (D'ARC, 2013). Ecological wisdom is concerned with the creation of healthy co-evolution of social and ecological systems (YOUNG, 2016; YOUNG et al., 2018) that brings together human behavior, economics, infrastructure, production, consumption, waste, use, relations to others, management, politics, buildings, planning, justice, as well as the environment. It builds on a comprehensive spectrum of social, ecological, historical, and philosophical sources (YOUNG et al., 2018). It is represented by a variety of approaches including biomimicry, green infrastructure, ecological restoration, and design for environment (YANG; LI, 2016; YOUNG et al., 2018). These approaches provide the opportunity to unify the objectives of the present and the needs of the future with knowledge of the past and the agency of nature. As Young et al. suggest (2018) this may provide a holistic and valuable experience particularly for preserving long-functional systems within growing medium-sized cities, while informing the responses and actions to unprecedented conditions, such as the potential impacts of technology, new emerging economies, climate change, or natural disasters.

Ensuring ecological wisdom in the design and experience of urban places can provide for the unique, positive possibilities that are part of medium-sized cities. While smart cities currently prioritize the integrate of cities with technological capabilities, ecological wisdom, as an approach, can bring a balance to integrate urban areas with nature, contemporary culture, technology, and the potential these components offer in medium-sized cities.

\section{CONCLUSION}

We are no longer merely imagining an open and shared urban future. The future is here. Advancing technologies and sharing economies are providing new opportunities in response to urban challenges that medium-sized cities currently face, particularly with transportation, privacy issues, and biodiversity. As technologies continue to evolve, businesses investing in the concept of sharing are causing changes in the use of public spaces and related social behaviors. As part of ongoing smart city discussions, planners, designers, and economists are looking into these concepts and questioning the sociocultural and economic effects of a sharing economy on the use of public space. It is apparent that there are spatial implications from these technologies and services, and the pressing need to envision the design of future urban public spaces with ecological wisdom and a human-centered focus.

Norman (2013) states that technologies might change, but the fundamental principles of interaction are permanent, and continue to apply in how our public spaces, such as streets, plazas, squares, and parks are able to accommodate human interactions. Although 
it requires careful consideration to accommodate the effects of technological advance (TENNER,1996; ANDERSON, 1978) it is possible for societal change to occur without any major structural or physical change related to social networks and mobility applications. The unintended or unexpected conditions of these technological changes could create urban public spaces that are unsafe or unsuccessful, and will therefore require research into the way we are reconfiguring the design of our current streets and public spaces, even our own homes. The idea of separate rooms or spaces linked by a corridor, alley, street, or hallway are now turning into more integrated and open spaces in relation to each other. The emphasis on publicness is reducing the friction between spaces but creating a challenge to accommodate safety (FURMAN, 2017).

This study is an inquiry into the impacts that new technologies and a rapidly expanding sharing economy seem to have on the way urban public spaces are generated, used, and changed. We have reviewed the idea that urban public space is a continuum from the most public, such as the street, to the most intimate privacy within our own homes. The focus of this discussion has been on evolving observations on how this spectrum is being revised or blurred by the technologies and socio-cultural and economic practices of the sharing economy, particularly with respect to new technical and economic models of sharing such as Airbnb, Uber, ZipCar, and Lyft. In the coming years, it will be incumbent on designers, planners, and researchers to accommodate and engage with these new technologies and effects of sharing. We must work toward urban solutions that anticipate potential challenges such as gentrification, while supporting and designing for new public and semi-public zones, such as recovered parking areas and street edges, with a humancentered focus and ecological wisdom.

\section{REFERENCES}

ALBINSSONI, Pia A.; PERERA, B. Yasanthi. Alternative marketplaces in the 21st century: building community through sharing events. Journal of Consumer Behaviour, v. 11: p. 303-315, 2012.

ANDERSON, Stanford. People in the physical environment: the urban ecology of streets. In: ANDERSON, Stanford. On Streets. Cambridge, MA: The MIT Press, 1978. p. 1-11.

BENEDICTUS, Leo. Chinese city opens 'phone lane' for texting pedestrians. The Guardian, September 15th, 2014. Accessed at: https://www.theguardian.com/world/shortcuts/2014/sep/15/china-mobilephone-lane-distracted-walking-pedestrians

BJH ADVISORS. Short changing New York City: the impact of Airbnb on New York City's housing market. Policy report prepared for Housing Conservation Coordinators and MFY Legal Services, 2016.

BOTSMAN, Rachel; ROGERS, Roo. What's mine is yours. London: Collins, 2010.

BRIGNULL, Harry; ROGERS, Yvonne. Enticing people to interact with large public displays in public spaces. In: INTERACT CONFERENCE. 1, 2003, Zurich. Proceedings ... p. 17-24.

CARMONA, Matthew; HEATH, Tim; OC, Taner; TIESDELL, Steve. Public places, urban spaces: the dimensions of urban design. Oxford: Architectural Press, 2003.

CARMONA, Matthew. Re-theorising contemporary public space: A new narrative and a new normative. Journal of Urbanism, v. 8, n. 4, p. 373-405, 2015. 
CHEN, Liqun. Cities in the era of sharing economy: from a perspective of urban space. Landscape Architecture Frontiers, v. 5, n. 3, p40+, June 2017.

$\mathrm{CHO}$, Im Sik. Re-framing urban space: urban design for emerging hybrid and high-density conditions. New York: Routledge, Taylor \& Francis, 2016.

CRAYTON, Travis J.; MEIER, Benjamin Mason. Autonomous vehicles: developing a public health research agenda to frame the future of transportation policy. Journal of Transport \& Health, v. 6, p. 245-252, 2017.

D'ARC, Morge. Ecological wisdom: what does it really mean?" Green Horizon Magazine, January 18th, 2013. Accessed at: https:/ / green-horizon.org/eco-wisdom/.

DOCKRILL, Peter. Self-driving cars could mean the end of parking spaces, and that's great for cities. ScienceAlert, February 29th, 2016. Accessed at: https://www.sciencealert.com/self-driving-cars-couldmean-the-end-of-parking-spaces-and-that-s-great-for-cities.

ELABD, Aliaa; HALLOWELL, George. A Research Approach for Urban Places: Exploring the Behavioral Aspects of a City Plaza. Spaces and Flows: An International Journal of Urban and ExtraUrban Studies, v. 4, p. 1-12, 2014.

FENTON, Amy. Making markets personal: exploring market construction at the micro level in the carsharing and time bank markets. Harvard University, 2013. (Unpublished paper).

FURMAN, Andrew. Exploring affordances of the street. International Journal of Sustainable Development and Planning, v.12, n.3, p. 606-615, 2017.

GEHL, Jan. Life between buildings: using public space. Copenhagen: The Danish Architectural Press, 1971.

GERON, Tomio. Airbnb and the unstoppable rise of the share economy. Forbes Magazine, February 11th, 2013. Accessed at: https://www.forbes.com/sites/tomiogeron/2013/01/23/airbnb-and-the -unstoppable-rise-of-the-share-economy/\#6cc24bbaaae3

GIBSON, James J. The theory of affordances. In: SHAW, R.; BRANSFORD, J.; HILLSDALE, N.J.; ERLBAUM. Perceiving, Acting and Knowing: Towards an Ecological Psychology. Hillsdale: Erlbaum Associates, 1977. p. 67-82.

HAMARI, Juho; SJÖKLINT, Mimmi; UKKONEN, Antti. The sharing economy: why people participate in collaborative consumption. Journal of the Association for Information Science and Technology v. 67, n. 9, p. 2047-2059, 2016.

JACOBS, Jane. The death and life of great American cities. New York: Random House, 1961.

KAYDEN, Jerold S. The New York City Department of City Planning, and The Municipal Art Society of New York. Privately owned public space: The New York City experience. New York: Wiley, 2000.

KILIAN, Ted. Public and private, power and space. In: LIGHT, A.; SMITH, J. The production of public space. Lanham: Rowman and Littlefield, 1998.

LEARY-OWHIN, Michael Edema. Exploring the production of urban space: differential space in three post-industrial cities. Bristol: Policy Press at the University of Bristol, 2016.

LEE, Dayne. How Airbnb short-term rentals exacerbate Los Angeles's affordable housing crisis: analysis and policy recommendations. Harvard Law \& Policy Review, n. 10, p. 229-253, 2016.

LEFEBVRE, Henry. The production of space. Oxford: Blackwell, 1991.

LEGRADY, George. Intersecting the virtual and the real: Space in interactive media installations. Wide Angle, v. 21, n. 1, p.105-113,1999.

LOUKAITOU-SIDERIS, Anastasia; EHRENFEUCHT, Irena; EHRENFEUCHT, Renia. Sidewalks: conflict and negotiation over public space. Cambridge, MA: The MIT Press, 2009.

LYNCH, Kevin. The Image of the City. Cambridge, MA: The MIT Press, 1960.

MADANIPOUR, Ali. Public and private spaces of the city. London: Routledge, 2003. 
MCFARLAND, Christiana. Mid-sized cities are the future of cities, here are three reasons why. Meeting of the Minds, Dec 4th, 2017. Accessed at: https://meetingoftheminds.org/mid-sized-cities-future-citiesthree-reasons-23946

MEHTA, Vikas. The street: a quintessential social public space. London: Routledge, 2013.

MITCHELL, William. City of bits: space, place, and the infobahn. Cambridge, MA: The MIT Press, 1995.

MOOG, Trevor. Belgian city launches 'text walking lanes' for smartphone addicts. Digital Trends, June 15th, 2015. Accessed at: https://www.digitaltrends.com/mobile/ belgian-city-launches-text-walkinglanes-for-smartphone-addicts/

MUMFORD, Lewis. The City in History: Its Origins, Its Transformations, and Its Prospects. New York: MFJ Book, 1997.

NORMAN, Don. The design of everyday things. New York: Basic Books, 2013.

PARIGI, Paolo; STATE Bogdan. Disenchanting the world: the impact of technology on relationships. In: AIELLO, L.M.; MCFARLAND, D. Social Informatics, v. 8851, p. 166-182, 2014.

PASALAR, Celen; HALLOWELL, George. Toward human-centered smart cities: understanding emerging technologies and their effect on the urban experience. In: AMPS, ARCHITECTURE MPS. 1, 2014, Phoenix. Proceedings ...

PECKENHAM, Emily. Talking public space and urban intervention with San Francisco's Rebar Studio. Inhabitat, June 10th, 2014.

RINNE, April. What exactly is the sharing economy? The World Economic Forum, December 13th, 2017. Accessed at: https:/ / www.weforum.org/agenda/2017/12/when-is-sharing-not-really-sharing/

ROJAS-RUEDA, David; NIEUWENHUIJSEN, Mark; KHREIS, Haneen. 1859 - Autonomous vehicles and public health: literature review. Journal of Transport \& Health, v.5, p. 13 June 2017. 13.

RYKWERT, Joseph. The street: the use of its history. In: ANDERSON, S. On Streets. Cambridge, MA: The MIT Press, 1978, p. 14-27.

SCHOR, Juliet. Debating the sharing economy. Journal of Self Governance and Management Economics, v. 4, n.3, p. 7-22, 2016.

SENNETT, Richard. The fall of public man. New York: Knopf, 1977.

SISSON, Patrick. The new magnetism of mid-size cities: for many millennials, second cities are becoming their first choice, Curbed, May $1^{\text {st }}$ 2018. Accessed at: https://www.curbed.com/2018/5/1/17306978/ career-millennial-home-buying-second-city.

TENNER, Edward. Why things bite back: new technology and the revenge effect. London: Fourth Estate, 1996.

TUSSYADIAH, Iis P. An exploratory on drivers and deterrents of collaborative consumption in travel. In: TUSSYADIAH, Iis P.; INVERSINI, Alessandro. Information \& Communication. Switzerland: Springer International Pub., 2015.

VOGEL, Daniel; BALAKRISHNAN, Ravin. Interactive public ambient displays: transitioning from implicit to explicit, public to personal, interaction with multiple users. In: UIST. 04, 2004, Santa Fé. Proceedings ... Accessed at: https:/ / www.dgp.toronto.edu/ ravin/papers/uist2004_ambient.pdf

YANG, Bo; LI, Shujuan. Design with nature: Ian McHarg's ecological wisdom as actionable and practical knowledge. Landscape and Urban Planning, v. 155, p. 27-32, 2016.

YOUNG, Robert. Modernity, postmodernity, and ecological wisdom: towards a new framework for landscape and urban planning. Journal of Landscape and Urban Planning, v. 155, p. 91-99, 2016.

YOUNG, Robert; LIEBERKNECHT, Katherine. From smart cities to wise cities: ecological wisdom as a basis for sustainable urban development. Journal of Environmental Planning and Management, v.6,n. 10, p. 1-18, 2018.

WACHSMUTH, David; WEISLER, Alexander. Airbnb and the rent gap: gentrification through the sharing 
economy. Environment and Planning A: Economy and Space, v. 50, n. 6, p. 1147-1170, 2018.

WACHSMUTH, David; CHANEY, David; KERRIGAN, Danielle et al. The high cost of short-term rentals in New York City. A Report from the Urban Politics and Governance Research Group School of Urban Planning, McGill University. January 30th, 2018.

WADUD, Zia; MACKENZIE, Don; LEIBY, Paul. Help or hindrance? the travel, energy, and carbon impacts of highly automated vehicles. Transportation Research Part A: Policy and Practice, v. 86, p. 1-18, 2016.

WALSH, Bryan. Today's smart choice: don't own. share. Time Magazine, March 17th, 2011. Accessed at: http://content.time.com/time/specials/packages/article/0,28804,2059521_2059717_2059710,00.html.

WORLD BANK. Who needs smart cities for sustainable development? 2012. Accessed at: http://www. worldbank.org/en/news/feature/2012/03/20/who-needs-smart-cities-for-sustainable-development

WHYTE, William H. The Social Life of Small Urban Spaces. Washington, DC: The Conservation Foundation, 1980.

Data de submissão: 12/ mar./ 2019

Data de aceite: 23/ jun./ 2019 